\title{
Godssystemets afvikling i Sønderjylland fra 1830-erne til 1864
}

\section{Af Hans Schultz Hansen}

En stor del af de sønderjyske bønder stod $\mathrm{i}$ fasteforhold til staten eller til private godsejere helt frem til 1800 -årene. Nogle ejendomme på de adelige godser skulle tilmed fortsat yde hoveri, og godsernes selvstandige retsvæsen og forvaltning udgjorde en risiko for vilkårlighed. I denne artikel belyses fæstevæsnets og hoveriets afløsning samt ophævelsen af godsernes særrettigheder i tiden frem til 1864 - i samspil med tidens politiske debat.

\section{Godssystemet i Slesvig indtil ca. 1810}

Godssystemet betegner den gamle landbrugsstruktur, hvor jorden ejedes af forholdsvis få godsejere, der bortfæstede brugsretten til afhængige bønder. Til gengæld præsterede fæsterne visse ydelser. Ved fæstemålets begyndelse betaltes et pengeindskud, indfæstningen. Den årlige leje, landgilden, blev ydet i form af naturalier som korn eller smør eller i penge. Endelig var der hoveriet, som bestod i pligten til at dyrke en del af godsejerens egen hovedgårdsmark. Som regel var hoveriet den afgiftsform, som var til størst ulempe for fæstebønderne, fordi den krævede ekstra heste- og folkehold og greb forstyrrende ind i driften af gårdene. Jo større hovedgårdsmarkerne var $\mathrm{i}$ forhold til bondejorden, jo større var hoveribyrden, jo ringere var bønderne stillet ${ }^{1}$.

Bortset fra Holsten var der næppe nogen anden europæisk region, der rummede så store forskelle fra sted til sted $\mathrm{i}$ forholdet mellem godsejere og fæstebønder som hertugdømmet Slesvig forud for landboreformerne i slutningen af 1700-tallet ${ }^{2}$. I marsken var bondeselvejet så dominerende, at det ikke giver mening at tale om noget godssystem her. I midtlandet og i det nordøstligste Slesvig tilhørte en større del af jorden bønderne selv, hovedparten dog den danske konge, som imidlertid fastede det ud på vilkår, der som helhed må betegnes som meget lempelige. Bønderne var således personligt frie, ejede selv bygningerne og var fra 1630-erne fritaget for at yde hoveri mod til gengæld at betale større pengeafgifter. Brugsretten til jorden var sikret for bondens efterkommere. 
De adelige godser fandtes især $\mathrm{i}$ den østlige del. Her var godssystemet skarpere udpræget, navnlig i det sydøstlige Slesvig med Svansen og Dänischwohld. I godsdistrikterne var alle bønder fæstere, her gjaldt livegenskabet, bønderne var pålagt store, ubestemte hoveribyrder og dertil i retslig og administrativ henseende udsat for godsejernes vilkårlighed, da adelen havde sit eget, selvstændige rets- og politivæsen på godserne. Godsejernes frihed var stor, de kunne således uden indgriben fra statens side nedlægge bøndernes fæstegårde og lægge jorden ind under hovedgården. Herregårdsmarkerne bredte sig derfor på bondegårdenes bekostning.

Landboreformerne betød en afgørende forbedring af fæstebøndernes vilkår ${ }^{3}$. De store statslige domænegårde blev udstykket. For adelens fæstere var det vigtigste, at livegenskabet blev ophævet i 1805, og at det fra samme år blev forbudt at inddrage fæstegårde til hovedgårdsmarker. Det ubestemte hoveri blev ligeledes forbudt. Fæstebøndernes arbejdsforpligtelser skulle nu fastsættes $i$ en skriftlig kontrakt. Med den voksende husmandsbefolkning var der imidlertid arbejdskraft nok til dyrkningen af herregårdsmarkerne, og godsejerne enedes $\mathrm{i}$ reglen med bønderne om at få større eller mindre dele af hoveriet afløst af en pengeafgift. På adskillige godser indførte ejerne ad frivillig vej arvefæstet, der gav bønderne væsentlig større sikkerhed for at nyde godt af deres arbejde med at forbedre landbrugsdriften. Mange steder frasolgtes fæstegårdene til bøndernes selvejendom. På flere godser valgte man endog at udstykke dele af hovedgårdsmarken.

Imidlertid blev der også efter landboreformerne adskillige levninger tilbage af det gamle godssystem. Godserne udgjorde fortsat selvstændige rets- og administrationsområder, der var fortsat et vist hoveri tilbage på nogle af godserne, og der var stadig bønder, som var fæstere, i det sydøstlige Slesvig endog på åremålskontrakter med ret detaljerede krav til driftsmåden og med usikker mulighed for forlængelse.

I denne artikel vil det blive undersøgt, om disse vilkår blev forbedret $\mathbf{i}$ årene efter 1830, og hvordan det $\mathrm{i}$ givet fald skete. Bøndernes repræsentation $\mathrm{i}$ de nye stænderforsamlinger og de bedrede konjunkturer gjorde det fra dette tidspunkt påtrængende at genoptage reformprocessen, som havde ligget stille under statsmagtens og landbrugets økonomiske krise siden 1814/ 1818. Der er i dette emne stof til flere bøger. Her er det kun muligt at redegøre for den vigtigste del af den politiske debat i stænderforsamlingerne og den lovgivning, som blev resultatet heraf. Endvidere er det hensigten at fremdrage de få samlede opgørelser over fæstevæsnet og give enkelte udvalgte eksempler på hoveriafløsningen, mest fra Nordslesvig. Det er mit håb, at der på denne måde kan lægges op til en dyberegående udforskning af problemstillingen. 


\section{Den slesvigske inddeling}

Indtil 1864 var administrationen af hertugdømmet Slesvig opdelt i fire kategorier":

1. Købstæderne, som falder uden for denne undersøgelse

2. De kongelige amter og landskaber

3. De adelige godser

4. Det øvrige privilegerede gods, som dels omfattede kloster-, kirke- og hospitalsgodset, dels de såkaldte oktrojerede koge i marsken (områder, som havde fået særlige privilegier for at fremme inddigningen).

I 1844 forsøgte man at få et samlet overblik over antallet af gårde og huse i hertugdømmerne, som man kunne sammenligne med den pålidelige danske hartkornsstatistik. Med den stærkt forældede struktur, den slesvigske forvaltning havde, var det en vanskelig opgave, som heller ikke lykkedes helt. I manglen af en moderne matrikel måtte man bygge på en hastigt gennemført fastsættelse af skatteværdien fra 1802, og der indkom ingen præcise oplysninger fra Tønder amts geestherreder. Tallene giver dog en fornemmelse af gårdenes fordeling på de forskellige led $\mathrm{i}$ administrationen ${ }^{\text {s: }}$ :

\begin{tabular}{|c|c|c|c|c|c|c|}
\hline 1844 & Huse u. jord & Huse m. jord & Gårde & Store gårde & Ialt & $\%$ \\
\hline Tdr. amts geest ${ }^{*}$ & \multicolumn{2}{|c|}{2175} & \multicolumn{2}{|r|}{1381} & 3556 & 8 \\
\hline Amter/landskaber & 4341 & 13463 & $1082 I$ & 716 & 29341 & 70 \\
\hline Private godser** & 1584 & 2528 & 2804 & 237 & 7153 & 17 \\
\hline Gejstligt gods & 298 & 176 & 187 & 6 & 667 & 2 \\
\hline Oktrojerede koge & 310 & 329 & 327 & 115 & 1081 & 3 \\
\hline Tilsammen & \multicolumn{2}{|c|}{25204} & \multicolumn{2}{|c|}{16594} & 41798 & 100 \\
\hline
\end{tabular}

Huse uden jord: I kilden benævnt "Landlose Stellen«

Huse med jord: Brug med indtil 960 rigsbankdaler skattepligtig værdi

Gårde:

Brug med 960-9999 rbd. skattepligtig vardi

Store gårde: Brug med 10.000 rbd. skattepligtig værdi og derover

* Tallene for Tønder amts geestherreder fra 1842 kan desværre ikke specificeres på huse med og uden jord eller gårde og større gårde.

** Inklusive de fyrstelige augustenborgske godser og Kær herreds gods.

Det fremgår, at $78 \%$ af de slesvigske landbrug lå i de kongelige amter og landskaber og dermed var enten selvejergods eller undergivet de yderst lempelige fæstevilkår her. Hertil bør lægges landbrugene i de oktrojerede koge og på det gejstlige gods, så samlet var over fire femtedele af de slesvigske bønder uafhængige af en privat godsejer. 


\section{Fæstevæsnet udenfor de adelige godsdistrikter}

Statistikken fra 1844 omfattede også en undersøgelse af besiddelsesforholdene. Landbrugene blev opdelt i fire grupper: selvejendom, arvefæstebrug, almindelige fæstebrug, hvor fæstemålet gjaldt på livstid, og endelig brug, der var fæstet på åremål. De tyske betegnelser for de fire kategorier var "Stellen in unbeschränktem Eigentum«, »Erbpachtstellen«, »Festestellen« og »Zeitpachtstellen«.

Fæstegodset i amter og landskaber blev af forvaltningen henregnet til de almindelige fæstebrug, men her er de opført som arvefæstebrug, eftersom forordningen af 14. april 1766 reelt lovfæstede arvefæstet, der i forvejen var sædvane. Fæstet gik i henhold til forordningen $\mathrm{i}$ arv til den ældste søn, eller hvis der ingen sønner var, til den ældste datter. Var der ingen børn, gik brugsretten til jorden $i$ arv til fæsterens søskende eller deres børn, om nødvendigt endnu fjernere arvinger. Kun hvis der slet ingen arvinger var, gik fæstet tilbage til kronen til ny bortfæstning ${ }^{6}$.

De kongelige fæstere behøvede imidlertid ikke at lade fæstet gå i arv. Med ubetydelige indskrænkninger stod det dem frit for at sælge eller pantsætte det. Salg til fremmede familier forudsatte ganske vist øvrighedens godkendelse, men den blev kun nægtet $\mathrm{i}$ absolutte undtagelsestilfælde. Indfæstningen i amterne var meget ringe, og den årlige landgilde og naturalieydelserne var forlængst smeltet sammen med de almindelige skatter?

Fæstevæsnets udbredelse i de enkelte amter og landskaber fremgår af tabellen ${ }^{8}$ øverst på side 145 .

Selvejendom var enerådende $\mathrm{i}$ marskområderne og på det nærmeste også $\mathrm{i}$ Husum og Bredsted amter samt på Fehmern. Arvefaste spillede en væsentlig rolle i Nordslesvig, hvor over halvdelen af gårdene var i arvefæste i Løgumkloster og Aabenraa amter samt i Haderslev Vesteramt. Også i Gottorp og Flensborg amter havde arvefæstet stor udbredelse, og antagelig lå Tønder amts geestherreder på samme linje9. Fæstevæsnet betød knap så meget i Hütten amt, Sønderborg-Nordborg amter og Haderslev Østeramt. Som lovgivningen var og praksis havde udviklet sig, havde forskellen mellem selveje og fæste i amterne imidlertid nærmest ingen reel betydning.

Incitamentet til at søge fasteafløsning var derfor ringe. I amterne var der her og der distriktsvis blevet foretaget afløsninger af fæstet i forbindelse med reguleringen af skov- og moseressourcerne og ved skyldsætningen i slutningen af 1700-tallet. Disse kollektive ordninger blev dog opgivet af regeringen ved landboreformernes afslutning. Men bønderne havde siden 1781 mulighed for individuelt at få afløst fæstet på meget billige vilkår. Ved engang for alle at 


\begin{tabular}{|c|c|c|c|c|c|c|c|c|c|c|c|c|}
\hline \multirow[b]{2}{*}{ Område } & \multicolumn{3}{|c|}{ Huse u. jord } & \multicolumn{3}{|c|}{ Huse m. jord } & \multicolumn{3}{|c|}{ Gårde } & \multicolumn{3}{|c|}{ Store gårde } \\
\hline & SE & AF F E & TF & & AF FA & TF & SE & AF FA & TF & SE & AF FE & TF \\
\hline Had.Ø. & $60 \%$ & $22 \%$ & $18 \%$ & $76 \%$ & $23 \%$ & $0 \%$ & $72 \%$ & $28 \%$ & $0 \%$ & $77 \%$ & $23 \%$ & $0 \%$ \\
\hline Had.V. & $25 \%$ & $35 \%$ & $40 \%$ & $42 \%$ & $58 \%$ & $0 \%$ & $38 \%$ & $60 \%$ & $2 \%$ & $71 \%$ & $25 \%$ & $4 \%$ \\
\hline Ábenrå & $80 \%$ & $19 \%$ & $1 \%$ & $51 \%$ & $49 \%$ & & $46 \%$ & $54 \%$ & & $89 \%$ & $11 \%$ & \\
\hline Logumkloster & $49 \%$ & $51 \%$ & & $9 \%$ & $91 \%$ & & $16 \%$ & $84 \%$ & & $50 \%$ & $50 \%$ & \\
\hline Tønder* & $97 \%$ & $3 \%$ & $\alpha \%$ & $100 \%$ & $0 \%$ & & $100 \%$ & & & $100 \%$ & & \\
\hline Sdr. og Nr.borg & $99 \%$ & $1 \%$ & $0 \%$ & $94 \%$ & $6 \%$ & $0 \%$ & $77 \%$ & $22 \%$ & $1 \%$ & $100 \%$ & & \\
\hline Flensborg & $82 \%$ & $9 \%$ & $9 \%$ & $73 \%$ & $27 \%$ & & $57 \%$ & $43 \%$ & $0 \%$ & $93 \%$ & $7 \%$ & \\
\hline Gottorp & $53 \%$ & $20 \%$ & $27 \%$ & $68 \%$ & $32 \%$ & & $53 \%$ & $47 \%$ & & $71 \%$ & $29 \%$ & \\
\hline Bredsted & $99 \%$ & $1 \%$ & $0 \%$ & $96 \%$ & $4 \%$ & $0 \%$ & $92 \%$ & $8 \%$ & & $100 \%$ & & \\
\hline Husum & $97 \%$ & $1 \%$ & $1 \%$ & $97 \%$ & $2 \%$ & $1 \%$ & $86 \%$ & $14 \%$ & $0 \%$ & $75 \%$ & $25 \%$ & \\
\hline Ejdersted & $90 \%$ & & $10 \%$ & $98 \%$ & & $2 \%$ & $95 \%$ & & $5 \%$ & $97 \%$ & $11 \%$ & $2 \%$ \\
\hline Stapelholm & $88 \%$ & $11 \%$ & $1 \%$ & $100 \%$ & & & $100 \%$ & & & $100 \%$ & & \\
\hline Hütten & $42 \%$ & $52 \%$ & & $56 \%$ & $44 \%$ & & $69 \%$ & $31 \%$ & & $11 \%$ & $89 \%$ & \\
\hline Pellworm & $100 \%$ & & & $99 \%$ & $0 \%$ & $0 \%$ & $99 \%$ & & $1 \%$ & $100 \%$ & & \\
\hline Fehmern & $100 \%$ & & - & $100 \%$ & & & $100 \%$ & & & $100 \%$ & & \\
\hline Ialt & $81 \%$ & $12 \%$ & $8 \%$ & $80 \%$ & $20 \%$ & $0 \%$ & $69 \%$ & $30 \%$ & $0 \%$ & $84 \%$ & $15 \%$ & $1 \%$ \\
\hline
\end{tabular}

$\mathrm{SE}=$ Selveje, $\mathrm{AF}=$ Arvefæste, $\mathrm{FE}=$ Almindeligt fæste, $\mathrm{TF}=$ Tidsfæste.

* Kun marskherrederne.

"- betyder, at denne form ikke forekommer. »0\%« betyder, at formen forekommer, men kun i så få tilfælde, at det er under $0,5 \%$ af det samlede antal brug i størrelsesklassen.

betale $2 \%$ af den skattepligtige jordværdi samt erlægge "Antrittsgeld « svarende til den hidtidige indfæstning, hver gang en ny ejer tiltrådte, kunne man opnå selvejendom ${ }^{10}$. Som det fremgår af tallene fra 1844 , var det imidlertid langtfra alle, der havde benyttet sig af den mulighed.

Trods mangelfulde oplysninger om udviklingen efter 1844 står dog klart, at 1850-erne blev vidne til mange afløsninger. I Haderslev amt var i 1864 kun ca. en fjerdedel af gårdene endnu i arvefæste mod omkring $37-38 \%$ i 1844 . I Tønder amts geestherreder var antallet af fæstesteder i 1855 reduceret til ca. $1253 \mathrm{mod}$ ca. 1660 i 1844. I Aabenraa amt var de fleste ejendomme i 1864 i selveje, men på Als var de tidligere augustenborgske gårde stadig overvejende $\mathrm{i}$ arvefæste, selvejendom var kun tildels indført ${ }^{11}$. Eksakte tal for afløsningen kan her kun gives for tiden 1856-66; da gik 1552 slesvigske fæstegårde fra fæste til selveje ${ }^{12}$.

Regeringen forsøgte at fremskynde den igangværende afløsning gennem lovgivningen. Den 16. april 1862 udsendtes loven om afløsning af arvefæstet på de kongelige domæner. En arvefæster kunne i henhold hertil få afløst selve fæstekvaliteten mod en gang for alle at betale $2 \%$ af jordernes taksationsværdi og $2 \%$ af bygningernes brandforsikringsværdi. Det var en forudsætning, at der var mindst 3 arvinger til gården $i$ live. For så vidt rummede loven en kodificering af de tidligere regler. Ønskede bonden ikke blot at slippe af med 
sin ejendoms fæstekvalitet, men også med den årlige canon (arveforpagtningsafgift), fik han nu mulighed for det ved at betale 25 gange den årlige canon en gang for alle ${ }^{13}$.

Derimod skulle der stadig betales tiltrædelsespenge ("Antrittsgeld «) af hver ny ejer. Den 27. november $1863 \mathrm{kom}$ der imidlertid en ny lov, der gav domænebestyrelsen ret til også at kræve tiltrædelsespengene afløst $\mathrm{i}$ forbindelse med afløsning af fæstekvaliteten. Prisen herfor var et beløb svarende til den oprindelige indfæstning. Hvis fæsteafløsningen fandt sted samtidig med et besidderskifte, skulle der oveni betales $60 \%$ af det oprindelige indfæstningsbeløb. Nye selvejere fra før lovens ikrafttræden, der havde beholdt forpligtelsen til at betale tiltrædelsespenge, kunne anmode om at få dem afløst ${ }^{14}$. De to nye love kom så kort tid for krigen i 1864, at de næppe kunne nå at få den store virkning. Selv om der var tale om et ret stort antal afløsninger i tiden mellem de slesvigske krige, var der derfor stadig en del fæstegårde tilbage i amterne ved indlemmelsen i Preussen i $1867^{15}$.

Forholdene på de gejstlige godser og i de oktrojerede koge mindede på hver sin vis om amterne. Mens selvejet $\mathrm{i}$ kogene var næsten enerådende som i de vestlige amter og landskaber, var fæstet stærkt udbredt på det gejstlige gods, som lå i det østlige Sydslesvig. Det udgjordes af Sct. Johannes klostergods, Flensborg hospitalsgods og godset til samme bys Marie og Nikolajkirker. Også her var der i realiteten tale om arvefæste ${ }^{16}$ :

\begin{tabular}{|c|c|c|c|c|c|c|c|c|c|c|c|c|c|c|c|}
\hline \multirow[b]{2}{*}{ Område } & \multicolumn{3}{|c|}{ Huse u. jord } & \multicolumn{4}{|c|}{ Huse $\mathrm{m}$. jord } & \multicolumn{4}{|c|}{ Gårde } & \multicolumn{4}{|c|}{ Store gårde } \\
\hline & SE & AF FAE & TF & & AF & $F A$ & TF & SE & AF & FA & TF & SE & $\mathrm{AF}$ & FE & TF \\
\hline Gejstligt gods & & $-99 \%$ & $1 \%$ & $9 \%$ & & $91 \%$ & & $9 \%$ & & $91 \%$ & & $14 \%$ & & $71 \%$ & $14 \%$ \\
\hline Koge & $96 \%$ & - & $4 \%$ & $95 \%$ & & $5 \%$ & $0 \%$ & $100 \%$ & & - & $0 \%$ & $94 \%$ & & - & $6 \%$ \\
\hline Ialt & $47 \%$ & $-50 \%$ & $3 \%$ & $62 \%$ & $3 \%$ & $35 \%$ & $0 \%$ & $65 \%$ & $0 \%$ & $34 \%$ & $0 \%$ & $89 \%$ & & $4 \%$ & $7 \%$ \\
\hline
\end{tabular}

\section{Fæstevæsnet i de adelige godsdistrikter}

I de adelige områder havde godssystemet også efter landboreformerne en vidt forskellig karakter. Adelsgodserne var inddelt i fire distrikter. Halvdelen af dem lå i Dänischwohld og Svans godsdistrikter. I denne del af Slesvig dominerede herregårdsmarkerne ganske. Medregnes skovene, udgjorde hovedgårdsarealerne omtrent tre femtedele af jorden; kun de sidste to femtedele udgjordes af bondegårde. I det 1 . angelske godsdistrikt, som bestod af godserne på Angelhalvøen, var rundt regnet en tredjedel af jorden herregårdsmarker eller godsejerskov. Hovedgårdenes betydning var endnu mindre i det 2 . angelske 
distrikt, som bestod af de spredt beliggende godser i Nordslesvig og den vestlige og midterste del af Sydslesvig. Kun omkring en syvendedel af jorden her blev dyrket under hovedgårde ${ }^{17}$. På hertugen af Augustenborgs godser på Als og omkring Gråsten udgjorde hovedgårdenes marker henholdsvis $23 \mathrm{og}$ $31 \%{ }^{18}$.

Bøndernes ejendoms- og fæsteforhold varierede også meget ${ }^{19}$ :

\begin{tabular}{|c|c|c|c|c|c|c|c|c|c|c|c|c|c|c|c|}
\hline \multirow[b]{2}{*}{ Område } & \multicolumn{3}{|c|}{ Huse u. jord } & \multicolumn{4}{|c|}{ Huse $m$. jord } & \multicolumn{4}{|c|}{ Gårde } & \multicolumn{4}{|c|}{ Store gårde } \\
\hline & SE & AF & FA TF & SE & $\mathrm{AF}$ & $\mathrm{F} \nexists$ & TF & SE & AF & $\mathrm{F} \boldsymbol{A E}$ & TF & SE & AF & FAE & TF \\
\hline 1.Angler Distr. & $63 \%$ & $5 \%$ & $6 \quad 4 \% \quad 28 \%$ & $84 \%$ & $9 \%$ & $1 \%$ & $5 \%$ & $85 \%$ & $14 \%$ & - & $1 \%$ & $100 \%$ & - & - & - \\
\hline 2.Angler Distr. & $72 \%$ & & $26 \% \quad 2 \%$ & $43 \%$ & $1 \%$ & $56 \%$ & $0 \%$ & $52 \%$ & $1 \%$ & $47 \%$ & $0 \%$ & $93 \%$ & - & $7 \%$ & - \\
\hline Augustenborg & $54 \%$ & & $-29 \% \quad 17 \%$ & $38 \%$ & - & $61 \%$ & $1 \%$ & $24 \%$ & $2 \%$ & $74 \%$ & $0 \%$ & $87 \%$ & - & $13 \%$ & - \\
\hline Svans & $24 \%$ & $22 \%$ & $6 \quad 4 \% \quad 50 \%$ & $21 \%$ & $22 \%$ & - & $57 \%$ & $37 \%$ & $36 \%$ & - & $27 \%$ & $70 \%$ & $12 \%$ & - & $19 \%$ \\
\hline Dänischwohld & $16 \%$ & $18 \%$ & $-66 \%$ & $3 \%$ & $23 \%$ & $0 \%$ & $73 \%$ & $4 \%$ & $45 \%$ & $0 \%$ & $50 \%$ & $52 \%$ & $28 \%$ & - & $20 \%$ \\
\hline ait & $48 \%$ & $9 \%$ & $14 \% \quad 29 \%$ & $41 \%$ & $9 \%$ & $31 \%$ & $20 \%$ & $46 \%$ & $17 \%$ & $25 \%$ & $12 \%$ & $76 \%$ & $11 \%$ & $3 \%$ & $11 \%$ \\
\hline
\end{tabular}

I 1. angler godsdistrikt var selvejendom efter de mange frasalg af gårde fra godserne under landboreformerne overalt aldeles dominerende, tildels dog med undtagelse af de jordløse huse. Kun bønderne under Bukhavn og Røst skilte sig rigtigt ud ved at være arvefæstere. Arvefæsterne på godserne havde ikke formelt ret til at sælge eller pantsætte gårdene, men godsejerne benyttede sig kun sjældent af deres forkøbsret og godkendte $\mathrm{i}$ de allerfleste tilfælde interesserede købere ${ }^{20}$.

I 2. angler distrikt var det almindelige fæste meget udbredt. Forholdene vekslede imidlertid meget fra gods til gods. I Nordslesvig var der selveje på de små godser Ballegård og Sandbjerg og bortset fra et par jordløse huse også på det lille gods Skovbølgård. Gram og Nybøl havde både selvejere og fæstere, men den reelle forskel mellem grupperne var ikke $s{ }^{21}$. Derimod dominerede fæstevæsnet aldeles på Søgård-Årtoft, Stoltelund og på de gråstenske godser, som tilhørte hertugen af Augustenborg. På Søgård-Årtoft var fæstet imidlertid reelt arvefæste ${ }^{22}$. Formentlig har det samme været tilfældet på de gråstenske godser. I hvert fald gjaldt det for hertugens godser på Als, at fæstebønderne her som fæsterne $i$ de kongelige amter ejede bygninger og besætninger og i det hele taget havde vilkår som disse, således ret til pantsætning og ret til salg efter indhentet tilladelse ${ }^{23}$. Efter den danske stats overtagelse af de augustenborgske og gråstenske godser efter Treårskrigen fik fæsterne også formelt samme vilkår som $\mathrm{i}$ amterne ${ }^{24}$.

Med helt få undtagelser var bøndernes fæsteforhold altså nærmest uproblematiske i de angelske godsdistrikter og i det augustenborgske og gråstenske distrikt. Helt anderledes så det ud i Svansen og navnlig i Dänischwohld. 
Her var den tidsbegransede bortforpagtning modsat alle andre steder i Slesvig stærkt udbredt. Denne fæsteform var forbudt $i$ kongeriget. For brug med over $6 \mathrm{tdr}$. land skulle der aftales et nærmere bestemt åremål for fæstet, på de små brug kunne fæstet løbe til opsigelse fra godsejeren ${ }^{25}$. I begge tilfælde stillede det fæsterne i en usikker position, også på de større brug, fordi de ikke kunne vide, om kontrakten eventuelt kunne forlænges ud over det aftalte åremål. Usikkerheden tilskyndede ikke til at gøre noget særligt ud af bygninger og jord, og navnlig savnede bønderne her det incitament til at forbedre bruget, som lå i sikkerheden for, at forbedringerne ville komme børnene til gode. I Svansen var det tidsbegrænsede fæste den dominerende form på 6 godser ud af 26, blandt andet Grünholz og Damp. I Dänischwohld fandtes den på alle 33 godser med undtagelse af fem, hvor der $i$ stedet var arvefæste.

Hertug Christian August of Augustenborg (1798-1869) var en af de mest markante skikkelser $i$ den slesvigske standerforsamling. som han var fodt medlem af. Hertugen var en dy'tig og dreven parlamentariker og derfor en farlig modstander, ikke alene for de danske nordslesvigeres reprasentanter, men ogsả for dem, der onskede at begranse godsejernes indflydelse. Når landboreformerne ikke kom nogen vegne for 1848, tilkom en stor del af aren ham. Efter sin tilslutning til den slesvig-holstenske revolution 1848-50 udvistes han af det danske monarki. Tegning og litografi i Historiske Samlinger for Son-

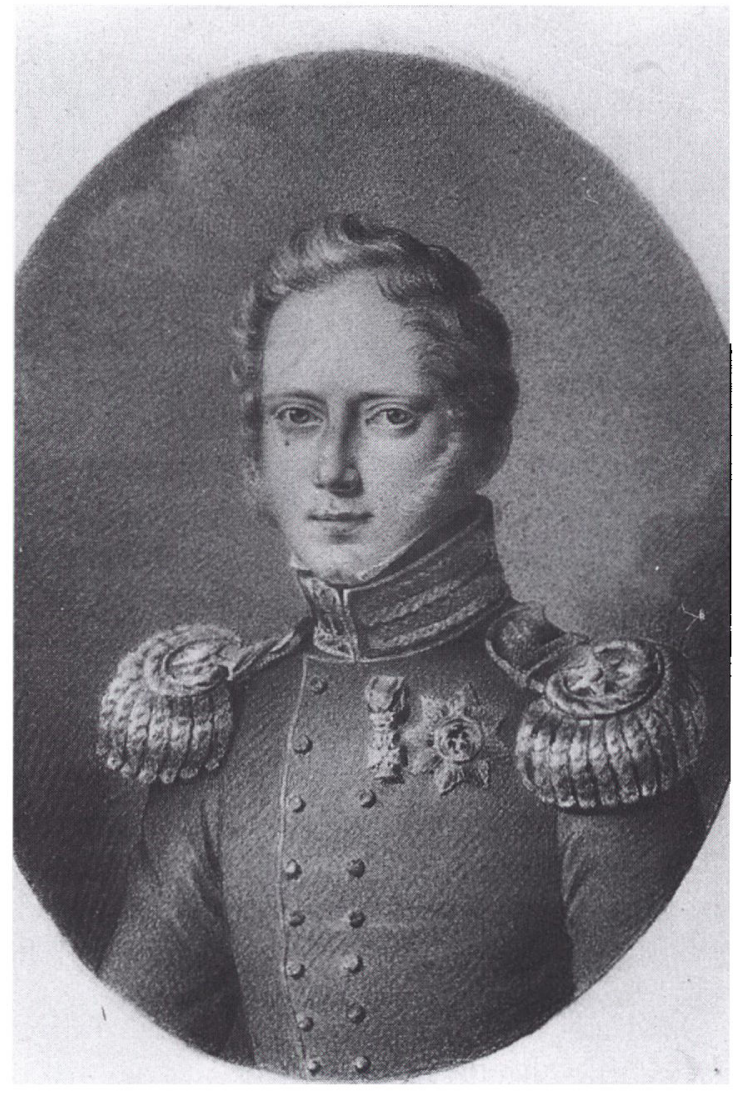
derjylland. 
Uden for hertugdømmet Slesvig, men dog geografisk i den sønderjyske region, lå godserne i de vestslesvigske enklaver: Trøjborg med Visby Hedegård og grevskabet Schackenborg. Trøjborgs fæstegods bestod af godt 940 tønder hartkorn, fordelt på 133 arvefæstegårde med ret til salg, 60 fæstegårde, 59 arvefæstehuse, 222 fæstehuse og 3 lejehuse. Til Schackenborg hørte lidt over 1950 tønder hartkorn fæstegods. Også her var hovedparten af fæstegårdene arvefæstegårde med ret til salg, nemlig 296 mod 29 fæstegårde. Af husene var $10 \mathrm{i}$ arvefæste, $510 \mathrm{i}$ almindeligt fæste og 124 var tyendehuse. Trøjborgs fæstegods overgik til selveje i begyndelsen af 1850-erne efter Knud Lausten Knudsens overtagelse. På Schackenborg gennemførtes fæsteafløsningen derimod først fra 1880-erne ${ }^{26}$.

Bortset fra Trøjborg gik fæsteafløsningen på godserne ikke nævneværdigt frem. Endnu i 1864 var fæstevæsnet stadig ganske udbredt, både arvefæstet og - hvad værre var - det tidsbegrænsede fæste, som fandtes i Dänischwohld og Svans i samme omfang som i $1844^{27}$.

Det tidsbegrænsede fæste var et stort problem for landbruget i de to sydøstlige godsdistrikter, men for det samlede slesvigske landbrug betød det kun lidt. Samles alle områder til een sum, fås følgende fordeling ${ }^{28}$ :

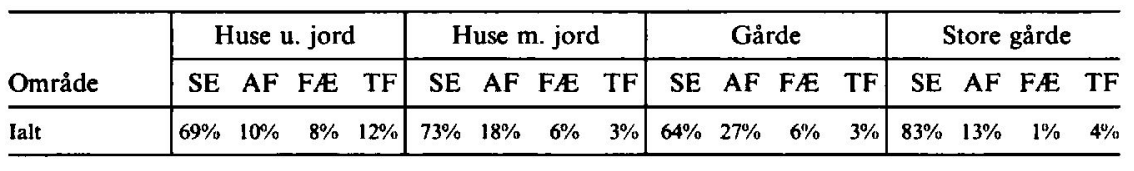

I hertugdømmet Slesvig som helhed var selvejet i 1844 den klart mest dominerende besiddelsesform, det gjaldt både de jordløse huse, huse med jord, gårde og større gårde. Selvejeandelen lå på omkring de to tredjedele. Af fæstebrugene var det store flertal i arvefæste, altså næsten i lige så fri besiddelse som selvejendommen. Det almindelige fæste (livsfæstet) betød kun lidt, åremålsfæstet bortset fra de jordløse huse endnu mindre. Efter landboreformerne sad det helt store flertal af de slesvigske landbrugere sikkert på deres brug. De havde derfor al grund til at forbedre deres landbrug - ingen godsejer skummede fløden af deres arbejde. I kongeriget var derimod endnu i $185033 \%$ af gårdene i almindeligt fæste eller i arvefæste uden ret til salg eller pantsætning, $48 \%$ af husene med jord og $63 \%$ af de jordløse huse ${ }^{29}$.

\section{Ophævelsen af godsernes retslige særstatus}

Bragte perioden fra 1830-erne til 1864 næppe nogen nævneværdig afvikling af fæstevæsnet på de private godser, var der andre felter, hvor det kom til 
indskrænkninger i godssystemet. Således på retsvæsnets område. De nærmere regler for retsvæsnet på godserne var fastsat i forordningen af 19. juli 1805 . Det var stadig op til godsejeren at udnævne dommeren, men valget skulle nu stadfæstes af kongen. Den udpegede skulle besidde kvalifikationer, der gjorde ham egnet til at beklæde et dommerembede. Efter indsættelsen skulle han aflægge ed. For at forhindre interessekonflikter var det forbudt at antage advokater som dommere, dog med undtagelse af over- og landretsadvokater. En dommer kunne være fælles for flere godser eller samtidig være kongelig embedsmand. Dommerens uafhængighed søgtes sikret ved, at de var uafsættelige. En godsejer kunne altså ikke skille sig af med en dommer, der dømte imod hans interesser ${ }^{30}$.

Forordningen betød utvivlsomt en opstramning af godsernes retsvæsen. Med politiforvaltningen skulle det imidlertid forblive som hidtil. Det var næppe godt nok. Ved patent af 19. september 1837 måtte regeringen foranlediget af efterretninger om mangelfuld forvaltning på nogle godser indskærpe, at godsejerne var ansvarlige for deres politibefuldmægtigedes handlinger. Selv om udpegelsen af sådanne fortsat helt lå i godsejernes hænder, forventede regeringen, at kun kvalificerede mænd blev udnævnt ${ }^{31}$.

På samme tid kom godsernes selvstændige retsvæsen, med et fremmedord deres patrimonialjurisdiktion, under angreb. I stænderforsamlingen i 1838 foreslog møllearvefæster Müller dens afskaffelse ${ }^{32}$. Müller var deputeret for 15 . landvalgdistrikt, som netop omfattede Svansen og Dänischwohld med de mange godser. Han androg nu om, at håndhævelsen måtte gå tilbage til kongen, hvorfra den i sin tid var blevet overdraget adelen. De nuværende tilstande kritiserede han heftigt. Godsejerne valgte sjældent de rigtige dommere (justitiarer), men ofte "uvidende og gode jasigere «. Dommerne boede gerne inde i byerne, langt fra godserne. De samlede 10,20 ja op til 30 justitiarembeder på én hånd, og om deres upartiskhed måtte man rejse tvivl, når man så, hvorledes de spiste og spillede kort sammen med godsejerne. Også godsernes politiforvaltning kritiserede han hårdt. Forordningen fra 1837 havde ikke virket, mange steder savnedes ordentlige fængsler, så beboerne følte sig usikre over for forbryderne. Mens kongen gennem årtier havde haft bondestandens vel for øje, havde stænderforsamlingerne endnu intet gjort til dens gavn. $\mathrm{Nu}$ var der en sag, som ikke tålte udsættelse.

De godsejere, som ytrede sig, var af en anden mening. Modargumenterne gik især på, at man først måtte vide, hvad man ville stille i stedet. Flere vedgik, at den nuværende retstilstand på godserne ikke var tilfredsstillende, men det var den heller ikke i de kongelige amter. Deciderede klager over godsernes dommere var der ingen eller kun få af. Endelig var patrimonialjurisdiktionen en rettighed, som adelen havde erhvervet på lovlig vis. Når man fra liberal 
side ønskede den ophævet, var det ifølge hertugen af Augustenborg kun en ren modesag. Fuld støtte i debatten fik Müller kun fra Peter Hiort Lorenzen fra Haderslev, og da der skulle stemmes om nedsættelsen af en komité, blev forslaget forkastet med 21 stemmer imod og 19 for.

Patrimonialjurisdiktionen var en økonomisk belastning for godsejerne, især på de mindre godser ${ }^{33}$. Når godsejerne alligevel holdt så fast på den, skyldtes det snarest politiske momenter: man ville nødig frivilligt give slip på et århundredgammelt privilegium. Gav man efter med hensyn til patrimonialjurisdiktionen, løb man risikoen for at miste flere og vigtigere privilegier. Denne opfattelse var fælles for ridderskabet, den mest privilegerede gruppe i den danske helstat, og for hertugen af Augustenborg, som sammen var de mest konservative kræfter i stænderforsamlingerne.

Den svage danske senenevælde havde imidlertid ikke mod på at tage en konflikt med det slesvig-holstenske ridderskab, der ikke besvarede en henvendelse om patrimonialjurisdiktionen i 1846. Men efter nedkæmpelsen af den slesvig-holstenske revolution 1848-50, hvori størstedelen af godsejerne havde deltaget, kom tiden for en modernisering. Fra 1850 mistede godsejerne og godserne meget af deres selvstændige stilling. I juli 1850 bortfaldt det særlige værneting, da landretten blev ophævet. Herefter skulle ejerne af de adelige godser som andre mennesker sagsøges for de almindelige underretter i den retskreds, de boede $i$, og godserne hørte fra nu af også som ejendomme herindunder ${ }^{34}$.

Godserne hørte oprindelig administrativt direkte under den slesvigske regering (overretten), fra 1834 under den fælles provinsialregering for Slesvig og Holsten. I oktober 1852 mistede godserne udenfor det sluttede godsområde i Østangel, Svans og Dänischwohld denne status bortset fra kirke- og skolesagerne. Godserne lagdes i stedet for ind under de tilgrænsende amtmænd, der udnævntes til kongelige kommissærer for godserne. For det sluttede godsområde indsattes en særlig kongelig kommissær ${ }^{35}$.

I 1853 nåede man til patrimonialjurisdiktionen. Ved patent af 3. juni 1853 blev den ophævet for de adelige godser, det adelige Sct. Johanneskloster og for de oktrojerede koge i Slesvig. En særlig årsag hertil var, at godsejerne efter nedlæggelsen af de særlige værneting kunne dømmes af den dommer, de selv havde indsat. Men patentet må også ses $\mathrm{i}$ sammenhæng med regeringens bestræbelser på at forenkle det administrative og retslige kludetæppe med de mange små jurisdiktioner. De godser, som lå udenfor det sluttede godsområde i Sydøstslesvig, lagdes i retslig henseende ind under herredstingene. For Svans og Dänischwohld oprettedes det nye Eckernförde herred, for de østangelske godser Kappel herred og af de nordstrandske koge Nordstrand herred ${ }^{36}$.

Patentet omfattede ikke militær- og næringssagerne samt det administrative 
politi, som fortsat lå hos godsejeren ${ }^{37}$. Alligevel var der modstand mod ophævelsen i stænderforsamlingen i 1853-54, hvor patentet skulle behandles. Et flertal på 24 deputerede mente ikke, at ophævelsen af patrimonialjurisdiktionen havde sikret en bedre retspleje, så længe enkeltdommerne ikke var afskaffet og erstattet af dommerkollegier, og så længe domstole og forvaltning ikke var adskilt. Patrimonialjurisdiktionen burde altså først afskaffes, når der blev foretaget en reform af retsvæsnet som helhed. Endelig krænkede ophævelsen historisk begrundede og anerkendte rettigheder. Flertallet måtte dog tage det skete til efterretning og foreslog derfor at opretholde patentet som provisorisk indtil der var truffet endelig afgørelse om den ophævede fælles slesvig-holstenske overappellationsret i Kiel ${ }^{38}$.

Det sidste viser, at der var gået nationalpolitik i stændernes behandling af denne sag som af så mange andre af tidens reformforslag ${ }^{39}$. Godsejernes patrimonialjurisdiktion var blevet en del af de mlandsrettigheder «, som den slesvig-holstenske bevægelse værnede om ved enhver given lejlighed. De øvrige 18 deputerede, de dansksindede og de helstatsloyale, afviste i deres mindretalsvotum flere provisoriske tilstande - dem havde befolkningen mærket nok til fra 1848. For dem var det givetvis kærkomment at mindske de slesvig-holstenske godsejeres indflydelse, og derfor anbefalede de at patentet giordes endeligt. Dette skete da også med et nyt patent af 6 . februar $1854^{40}$. Et andragende i stænderforsamlingen 1855 fra baron Hobe til Gelting på at genindføre patrimonialjurisdiktionen førte selvfølgelig ikke til noget ${ }^{41}$.

\section{Hoveriafløsningen}

Godsejerne i stænderforsamlingerne modsatte sig også lovgivning på hoveriområdet. For de godser, hvor fæstebønderne efter landboreformerne fortsat ydede hoveri, var der med forordningerne af 19.12.1804 og 17.7.1805 fastsat nærmere bestemmelser. Herefter kunne hoveri kun ydes i henhold til en kontrakt (»hoveriforening «) mellem godsejer og fæster. Det ubestemte hoveri blev forbudt. Der skulle holdes nøje regnskab med, hvor meget hoveri den enkelte havde præsteret. Ved overretten skulle der udpeges to landbrugskyndige, som kunne behandle klager over hoveriet ${ }^{42}$.

Efter 1805 havde hoveriet altså langtfra den samme betydning som førhen. Alligevel var der flere rester af denne feudale ydelse tilbage endnu i 1830-erne. Det drejede sig især om kørsler med korn, hjælp til byggearbejde, vedligeholdelse af hegn og veje og lignende, men regulært avlingshoveri fandtes også. Hoveriet bevaredes også på flere godser, hvor der reelt var arvefæste for bønderne. 
I Nordslesvig blev de augustenborgske og gråstenske godser således drevet med et vist avlingshoveri. På de gråstenske godser i Aabenraa amt og i Sundeved nåede hertugen og bønderne frem til overenskomster om afløsning før Treårskrigen ${ }^{43}$. På Årup anmodede bønderne i 1839 om at få afløst hoveriet med en pengeafgift, dog bortset fra jagter og herskabskørsler. Hoveriet var ikke særligt belastende og stod mest i forbindelse med høhøsten, hvor der af en halvgård skulle ydes ialt $171 / 2$ dag. Dertil kom en dag med javning af engene, 1 1/2 dags reparationsarbejde ved bygningerne og 4 dage med vejforbedring. Arbejdet bestod altovervejende i gangdage. Godsadministrationen satte værdien af arbejdet til $8 \mathrm{rdl} .10$ sk., men hertugen forlangte $11 \mathrm{rdl}$. i årlig afløsning. Den hoppede bønderne imidlertid ikke på, og i 1842 sagde de nej til tilbuddet. I 1844 fremkom de med en ny anmodning, hvor de tilbød at betale $9.200 \mathrm{mk}$. en gang for alle for at få afløst hoveriet. Efter at bønderne i 1845 havde forhøjet beløbet til $10.000 \mathrm{mk}$. godtog hertugen det i januar 1846 .

Også på Avnbølgård blev resultatet en afløsning med et pengebeløb en gang for alle. Belastningen var nogenlunde som på Årup, idet værdien af hoveriet efter bøndernes ansøgning om afløsning i 1843 her sattes til 8 rdl. 6 sk. Hoveriet bestod i $41 / 2$ pløjedage, 11 dage i høhøsten med slåning, rivning, indkørsel og opsætning, 6 dage i kornhøsten med tilsvarende opgaver, 3 dage med gødningskørsel, 2 dage med reparationsarbejde og en kørsel (ægt), altså ialt godt 20 dage.

Hoveriet på Kjelstrup blev efter bøndernes anmodning om afløsning i 1845 sat til en værdi af 8 rdl. 14 sk., altså svarende til Arup og Avnbøl. Udover 4 hånddage $\mathrm{i}$ hø- $\mathrm{og}$ kornhøsten bestod hovarbejdet $\mathrm{i}$ tørvelevering, træfældning og vejforbedring. Afløsningen fandt sted i 1846 med et beløb en gang for alle på 200 rdl. af hver halvgård.

De nævnte afløsninger foregik ikke helt gnidningsløst. Der gik nogen tid med afvisning af anmodninger og tilbud og fremsættelse af nye tilbud, men sagen blev dog klaret uden inddragelse af udenforstående instanser. Hertugen var ikke modstander af hoveriafløsning som sådan, men han ville have sin pris. Så let gik det ikke på Kiding og Fiskebæk. 1834 klagede bønderne i Tråsbøl og Bovrup over at skulle køre gødning ud i såtiden, og i 1836 forlangte de, at lensfogden skulle være til stede under hovarbejdet. I 1837 anmodede de forste gang om afløsning, men forgæves, og en fornyet anmodning i 1838 forblev også resultatløs. Hoveriet bestod da af 8 dages pløjearbejde, 5 dage med mejning af korn, 5 dage med indkørsel af korn (med to mand og spand og vogn), 4 dages mejning $\mathrm{i}$ høhøsten og 4 dages indkørsel, 3 dages møgkørsel med to mand og spand samt hånd- og spandtjeneste ved reparation og nybygning. Med ialt 37 dage, heraf de fleste som spanddage, foruden bygningshoveriet, var bønderne under Kiding og Fiskebæk spændt klart hårdere for end på 
de øvrige hovedgårde. Afløsningssummen blev da også sat til årligt 35 rigsdaler af en halvgård. Det var mere, end bønderne ville give.

I august 1840 overgav bønderne sagen til kong Christian VIII, da han rejste gennem egnen. I oktober samme år indsendte de en petition til stænderforsamlingen, hvor de fremstillede deres belastede situation og bad forsamlingen om at understøtte henvendelsen om hoveriafløsning til kongen. Her fik de imidlertid ingen hjælp. Den nedsatte petitionskomite afviste sagen som stænderforsamlingen uvedkommende; den måtte ikke blande sig i privatretslige forhold. Samme skæbne overgik en petition fra godsernes kådnere, der ydede 3 hovdage ugentlig ${ }^{44}$. Den dybereliggende grund til afvisningen var nok, at hovedparten af de slesvig-holstenske liberale netop havde sluttet alliance med hertug Christian August af Augustenborg i arvefølgesagen.

Derefter fortsatte de gamle forhold frem til 1846, hvor bønderne under Kiding og Fiskebæk påny rettede henvendelse efter hoveriafløsningerne på Årup, Avnbølgård og Kjelstrup. Denne gang enedes man om en afløsningssum på 650 rdl. for hvert halvbol en gang for alle. Året efter fik kådnerne tilbud om afløsning for 150 rdl. pr. ugedag. Det gik de ind på, men havde kun betalt en lille del i 1852. Kådnerne under Gråsten hovedgård opnåede først afløsning efter 1850 .

På de augustenborgske forpagtergårde på Als var kampen om afløsning af hoveriet ikke mindre sej. Her gik konfrontationen mellem gårdmændene og hertugen tilbage til 1806. Parterne havde ikke kunnet blive enige om en hoveriordning, og overretten havde måttet afgive kendelse i sagen. Den gik imod bønderne, som hævdede, at hoveriafløsningspengene for det afløste hoveri blev 3-4 doblet, mens resthoveriet forøgedes til det dobbelte, spandtjenesten til det tredobbelte. Bønderne nægtede at rette sig efter det nye hoverireglement, og der måtte anvendes militære magtmidler for at få dem til at lystre. En appel til kongen i 1822 endte i 1828 med et afslag. Men nu havde stænderforfatningen påny tændt deres håb om en $\mathrm{i}$ deres øjne retfærdig afgørelse.

Deri blev de imidlertid skuffede. Hertugen af Augustenborg fandt ikke, at sagen vedkom forsamlingen, men påpegede dog, at bønderne havde tabt sagen ved talrige instanser. Han mere end antydede, at petitionen ikke var bøndernes eget værk. "Hvad forfatteren af petitionen har lagt de undergivne i munden, derpå vil han ikke spilde et ord«, hedder det således i stændertidendens referat. Stænderforsamlingens flertal ville heller ikke bruge tid på petitionen, og det afviste nedsættelsen af en komite ${ }^{45}$.

I slutningen af 1840-erne udgjorde det resterende, ikke afløste hoveri: 5 pløjedage om foråret og 3 om efteråret, en karl og en pige 5 dage $i$ hø- og kornhøsten, en karl med spand og vogn samt en pige 5 dage til indkørsel af hø og korn, gødningsudkørsel og 6 korte og 3 lange ægter. Den moderne 
indstillede godsejer Wilhelm Hirschfeld, Gross Nordsee, som i 1847 besøgte godserne, mente, at dette hoveri var mere til gene for bønderne end det havde værdi for godsdriften. Hoveriet skulle således ydes i den tid, hvor bønderne selv var travlest beskæftigede på deres marker, der gik megen tid til spilde ved hen- og tilbageturen fra og til gårdene, og tjenestefolkene tilbragte ofte meget mere tid end nødvendigt på hovedgårdene, når de skulle yde et bestemt kvantum arbejde til en fastsat tid. Bønderne måtte på grund af hoveriet regne med at skulle holde et spand heste og en karl mere, end hvad der var nødvendigt til driften af deres egen gård. Hirschfeld støttede derfor det tilbud, hertugen havde givet bønderne om at få afløst hoveriet for $20 \mathrm{rdl}$. årligt.

Han fremhævede, at bønderne på fastlandet havde antaget dette tilbud, hvilket hang sammen med, at det tyske element dér var det fremherskende (sic!). På Als lod mange det imidlertid blive ved det gamle, »da de propagandistiske ideer, som indpodes i dem, afholder dem fra at antage tilbuddet, til skade for dem selv«. Hirschfeld så altså hoveristriden i lyset af de skærpede modsætninger mellem den slesvig-holstenske hertug og hans dansksindede bønder ${ }^{46}$.

Det er da også rigtigt, at den danske bevægelse forsøgte at vinde indpas blandt bønderne på Sydals og i Sundeved ved at støtte dem overfor hertugen. Modsætningsforholdet mellem bønderne og hertugen rakte imidlertid tilbage til før den nationale konfrontations tid. Det var snarere den danske bevægelse, der byggede videre på dette og gav det en nationalpolitisk dimension. Det gjaldt ikke kun $i$ hoverisagen, men også i sagen om hertugens jagtrettigheder på bøndernes jorder, som gav anledning til megen strid i stænderforsamlingerne. Her var som i så mange andre sager Peter Hiort Lorenzen fra Haderslev hertugens skarpeste modstander ${ }^{47}$.

Da hertugen efter sin tilslutning til den slesvig-holstenske revolution i marts 1848 blev tvunget til at flygte fra Als, vejrede bønderne naturligvis morgenluft i hoverispørgsmålet. »Mange begyndte at tro sig fritagede for alle forpligtelser overfor hertugen, navnlig canon..., skyldkorn, 18 dages hoveri i høst og vår«, skriver biskop Jørgen Hansen i sine erindringer. Biskoppen fik imidlertid standset selvtægten ved at hævde, at godserne nu tilhørte kongen, og det havde bønderne respekt for ${ }^{48}$. Mens den øvrige del af hertugdømmet i større eller mindre tidsrum var besat af tyske tropper, forblev Als hele tiden på danske hænder. Der dannedes i august 1848 et folkeråd for øen, som straks tog bøndernes ønske om at slippe for hoveriet på sin dagsorden ${ }^{49}$. I februar 1849 indsendte rådet et andragende om hoveriafløsning til det slesvig-holstensklauenborgske kancelli. Kancelliet afviste, at folkerådet havde noget at skulle have sagt $i$ dette private anliggende, men gav dog løfte om nedsættelsen af en 
Johann Georg Kittel (17971888) var skibsrederson fra Arendal i Norge, men bosatte sig som ung i Flensborg. En lotterigevinst satte ham i 1822 i stand til at kobe Skovbolgård ved Felsted. Som godsejer her kom han snart i nar kontakt med den augustenborgske hertug. Efter at Kittel i 1841 kom ind $i$ standerforsamlingen som godsejerreprasentant, blev han en trofast stotte for hertugens slesvig-holstenske politik. Kittel delte også dennes afvisende holdning overfor landboreformer ad lovgivningens vej og modsatte sig således mere lidenskabeligt end fikst en lov om hoveriaflosning. Kittel solgte Skovbolgård i 1880 . Foto efter Sonderjyllands Historie $I V, s$. 265.

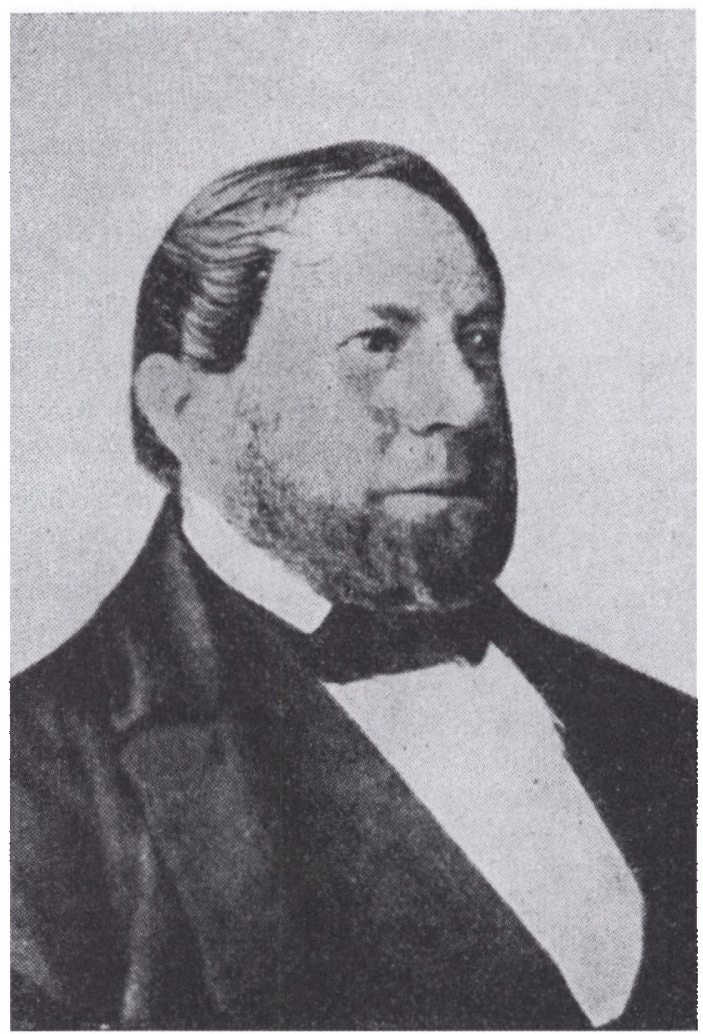

kommission til at afgøre spørgsmålet. Indtil afgørelsen var truffet, skulle bønderne yde det sædvanlige hoveri, om nødvendigt under tvang.

Den nedsatte kommission bestod af godsinspektør Richter fra Slagelse, amtsforvalter von Holstein fra Tønder og synsmand Duus fra Skovby. I oktober 1849 vedtog den at se bort fra de tidligere forhold og i stedet fastsætte den årlige afløsningssum til 17 rdl. cour. for en helgård. Bønderne kunne også vælge en gang for alle at indbetale 425 rdl. Hoveriet skulle ophøre fra 1. maj 1850 , men de endelige overenskomster blev først indgået i oktober $1851^{50}$. Ved at nægte at modtage hertugens tilbud fra før 1848 sparede bønderne altså 3 rdl. årligt.

På de fleste øvrige godser i Nordslesvig var hoveriet endnu mere beskedent end på de gråstenske og augustenborgske godser. På Gram og $N y b ø l$ godser bestod det $\mathrm{i}$ bygningsreparationsarbejde, ægter og hegnsvedligeholdelse. Sidstnævnte afløstes i slutningen af 1850-erne, hvorimod i hvert fald ægtkørslerne endnu bestod i 1881. Avlingshoveri forekom derimod ikke ${ }^{51}$. På Søgård og 
Artoft godser fastsattes hoveriet i 1838 til kørsel med byggematerialer, befordring af inspektøren, postgang, levering af tørv til inspektoratet samt af en helgård 4 klappere til jagten. Heri var ingen ændring sket i $1862^{52}$. På det lille gods Skovbølgård havde godsejer Kittel derimod bl.a. krav på 21 høstdage fra de jordløse husmænd ${ }^{53}$.

Hvordan forholdene stillede sig i Sydslesvig, er det vanskeligt at skaffe præcis underretning om. Formentlig var hoveriet afløst de fleste steder. I Svans var det $\mathrm{i}$ hvert fald sjældent allerede i 1820-erne, men fandtes dog på godserne Maasleben, Saxtorf, Hemmelmark og Rögen, hvorfra 108 fæstere i 1840 indgav en petition til stænderforsamlingen med anmodning om hoveriafløsning - lige så forgæves som deres standsfæller fra Bovrup og Tråsbøl . To eksempler på ikke-afløst hoveri fra Sydslesvig kan anføres. På Røst i Angel havde godsejeren krav på 10 karle- og 5 pigedage á 10 timer i sommerhalvåret. På Carlsburg i Svans var forpligtelsen på 10 karle- og 10 pigedage årligt. Begge steder godtgjorde godset hoveriarbejdet med en pengesum, og det var normalt kun at udnytte en mindre del af forpligtelsen ${ }^{54}$.

På de to godser var hoveriet således mindre omfattende end på hertugen af Augustenborgs godser, og sandsynligvis lå det $\mathrm{i}$ underkanten af, hvad der var normalt på godserne i Svans og Dänischwohld. Da den deputerede for disse godsdistrikter, gårdejer J. D. Arp, i stænderforsamlingen i 1857 fremsatte et andragende, om at regeringen ville forelægge et udkast til en hoveriafløsningslov, nævnte han således, at hoveriet bestod i 20-30 dage årligt. Det svarede ganske godt til gennemsnittet af de augustenborgske og gråstenske godser. Arp mente, at dette hoveri var til stor skade for bønderne, men til ringe gavn for godsejerne, og en afløsning ville derfor komme begge parter til gode.

Sådan så ikke alle godsejere på det. Kammerherre von Ahlefeldt-Saxtorf ville afvise Arps andragende, alene fordi han havde brugt betegnelsen "Frohndienste $\mathrm{i}$ stedet for "Hofdienste«. Det kunne hverken præsidenten eller Laurids Skau se nogen fornuft i. I overensstemmelse med sin taktik med at splitte det slesvig-holstenske flertal med forslag om økonomiske og sociale forbedringer gik Skau ind for, at der blev nedsat en komité. Det samme gjorde to andre dansksindede medlemmer, Krüger fra Bevtoft, og Bladt fra Als samt fabrikant Clausen fra Kappel. Stænderforsamlingens flertal fulgte denne indstilling og nedsatte en komité med Arp, Skau og Clausen. Imidlertid nåede den ikke at forelægge nogen betænkning, før samlingen var forbi ${ }^{55}$.

Imidlertid genfremsatte Arp sit forslag i 1860, hvor det var mindst lige så ubehageligt for det slesvig-holstenske parti ${ }^{56}$. Johan Plesner betegner sikkert med rette Arp som »en stædig venstremand uden større sans for det nationale $\aleph^{57}$. Selv om han var slesvig-holstener, ville han ikke underordne sig partidisciplinen, som især bestemtes af godsejerne. Arp fik støtte bl.a. af synsmand 
Bladt fra Als, der kunne henvise til den gavnlige afløsning af hoveriet på de augustenborgske godser. Fordelene var imidlertid ikke kun af materiel art: "Men der er imidlertid vundet langt mere $\mathrm{i}$ åndelig henseende, thi nu ser man langtfra ikke op til sine foresatte med den slaviske ængstelighed og mistro, som tidligere, nu føler man sig derimod mere som fri og selvstændig mand ligeoverfor enhver."

Dermed ramte Bladt nok sagens kerne. Hoveriets omfang var vel i det slesvigske stort nok til at være generende for bønderne, men langtfra stort nok til at være ødelæggende. Selv om de ikke personligt forrettede hoveriet, men sendte deres tjenestefolk, føltes hoveripligten imidlertid stadig mere og mere som en ydmygelse af bønderne. Ikke fordi den var blevet skærpet, men fordi bondens verden $\mathrm{i}$ den grad havde ændret sig efter 1830 , både socialt og politisk.

I komiteen fik de to gårdmænd Arp og A. Hansen fra Grumby og godsejer Schmidt, Vindeby sæde. Mens Arp og Hansen ønskede en lov om hoveriafløsning forelagt næste stænderforsamling, gik Schmidt imod at lovgive om private kontraktforhold. Den mest indædte modstand leverede dog godsejer Kittel, Skovbølgård, der som næunt stadig drev sin gård med hovdage. Han fandt de mange klager over hoveriet ubegrundede, når $\mathrm{i}$ hvert fald gangdagene for størstedelen blev udført af husmænd, som gårdmændene lejede dertil. Det var også forkert, at hoveriet ikke havde nogen større værdi for godsejerne. Netop i hø- og kornhøsten var det vigtigt, at der var folk nok, og det kunne blive svært at skaffe tilstrækkelig arbejdskraft på anden vis i disse spidsbelastningsperioder. Denne tankegang har formentlig været årsagen til, at godsejerne mange steder undlod at afløse alt hoveri efter forordningen fra 1805.

I øvrigt mente Kittel, at det var farligt at forlade kontraktligt fastsatte rettigheder: "Man dømme nu om sagen som man vil, så tror jeg dog ikke, at nogen vil bestride den sætning, at, frem for alt, retsprincippet bør varetages; men dette punkt, synes mig, bliver der ikke taget tilstrækkeligt hensyn til her i salen. Når man ikke længere respekterer kontraktsforhold, så styrer vi lige løs på kommunismen«. Til dette sagde provst Hansen, at der jo skulle udbetales erstatning til godsejerne, men Kittel fastholdt sin skrækvision. Han havde ingen tiltro til en retfærdig erstatning. Afløsningskommissioner med en øvrighedsperson som opmand ville blot give bønderne ret. Man kunne lige så godt sige til folk: "læg penge og gods og alt, hvad I har, sammen, og lad det så blive delt .

Kittel forsøgte at aflede angrebet på godsejernes wfriheder og rettigheder" ved at henvise til det kommunale hoveri. Denne tråd blev taget op af rådmand Thomsen, Oldensworth, der som fører for det slesvig-holstenske parti måtte 
ning. Dette afholdt dog ikke Ministeriet for hertugdømmet Slesvig fra at gå $\mathbf{i}$ gang med at udarbejde et lovudkast til forelæggelse for stænderne i 1863. Til brug for forarbejdet indhentede ministeriet opgørelser over hoveriet fra kommissærerne for de adelige godser, men desværre er disse skemaer ikke bevaret ${ }^{58}$.

Udkastet nåede imidlertid ikke til diskussion i stænderforsamlingen i 1863, der sluttede den 17. juli efter kun en dags møde med, at de slesvig-holstensksindede en efter en udvandrede i protest mod de forudgående stændervalg. Den slesvig-holstener, som sidst forlod sin plads, var gårdejer Arp, der uden tvivl ærgrede sig over endnu engang at se sin hoveriafløsningssag udsa $t^{59}$. Men han kunne så glæde sig over, at udkastet i stedet udsendtes af regeringen som en provisorisk anordning den 6 . september $1863^{60}$.

Ifølge anordningen skulle indgåelsen af aftaler om hoveri herefter forbydes. En gods- eller gårdejer måtte dog stadig indgå arbejdskontrakter med sine husmænd, men disse kontrakter måtte ikke stå i forbindelse med lejekontrakten, og de måtte højst gælde for et år ad gangen. Det eksisterende hoveri skulle afløses med en årlig pengeydelse, når en af parterne forlangte det, enten godsejeren eller halvdelen af de hoveripligtige. Kunne man ikke blive enige om en afløsningssum, skulle sagen ordnes ved offentlig foranstaltning. Til det formål skulle der udpeges en afløsningsformand for hele hertugdømmet. Sammen med to voldgiftsmænd valgt af parterne var det hans opgave først at forsøge mægling, men dernæst, hvis denne mislykkedes, at fastsætte afløsningssummen. Endvidere påbød anordningen nedsattelse af en appelkommission.

Noget andet er så, om denne provisoriske anordning overhovedet nåede at få nogen virkning, for krigen brød ud mindre end et halvt år efter. Den førte vel til ansøgninger fra bønderne, men om sagerne blev færdigbehandlet, er tvivlsomt, og den 30 . april 1864 blev anordningen suspenderet ${ }^{61}$.

\section{Sammenfatning og udblik}

Efter stænderforsamlingens indførelse blev afviklingen af godssystemet i Slesvig hurtigt til politik, ikke alene erhvervspolitik, men snart også nationalpolitik. Stænderforsamlingens flertal bestod mest af liberale, slesvig-holstenske akademikere $\mathrm{i}$ alliance med konservative godsejere, og bønderne var ikke tjent med, at liberalismens doktrin om statens ikke-indblanding $\mathrm{i} ø$ økonomiske forhold kom til at gå hånd $\mathrm{i}$ hånd med godsejernes indædte privilegiehævdelse overfor den danske statsmagt.

Den danske stats vilje til at tilsidesætte stænderforsamlingens flertal viste 
sig kun at være halv. Patrimonialjurisdiktionen blev ophævet, men ikke godsejernes administrative beføjelser. Noget længere gik man med hoveriafløsningen uden dog at gøre den tvungen. Først og sidst nøjedes man med at fremme fæsteafløsningen $\mathrm{i}$ amterne, hvor behovet ikke var så påtrængende, mens man intet foretog sig for at få afskaffet det for bønderne så ufordelagtige tidsbegrænsede fæste.

I kongeriget var tempoet $\mathrm{i}$ reformlovgivningen hurtigere, og lovene greb mere ind til fordel for bonderne. Gårdmandshoveriet skulle f.eks. i henhold til hoveriloven af 1851 afløses, når blot en tredjedel af bønderne krævede det. Samtidig virkede staten gennem en række love fra begyndelsen af 1850-erne og fra 1861 ikke alene for at afløse fæstevæsnet på statens eget gods og på institutionsgodserne, men også på de private godser ${ }^{62}$. Fæstevæsnets større udbredelse i Danmark bidrog uden tvivl til at gøre reformerne mere påtrængende her, og presset fra bondestanden var større. I Slesvig var reformer derimod kun virkeligt påkrævede for et lille mindretal af bønderne - som til gengæld havde endnu større behov for dem end de danske fæstebønder.

Den preussiske stat kørte $i$ hovedsagen videre $i$ det samme spor som den danske regering. Ved omlægningen af administrationen efter Slesvigs indlemmelse i 1867 blev der stadig indrømmet godserne en særstatus. De blev således holdt udenfor den landkommunale inddeling som særlige godsdistrikter med godsejeren eller godsinspektøren som "godsforstander «. Der var hverken kommuneforsamlinger eller kommuneråd som i landkommunerne, altså slet intet lokalt demokrati. Indtil 1888 fortsatte godserne med at have selvstændig politimyndighed udenfor herredsfogdernes myndighed. På mange måder vedblev det i realiteten også efter indførelsen af amtsforstanderne i 1888, da regeringen med forkærlighed udpegede godsejere til dette hverv. Nævnes bør også den særlige repræsentation for de store grundejere i kredsdag og provinslanddag ${ }^{63}$. Først efter kejserrigets fald i 1918 forsvandt disse særrettigheder.

Den preussiske politik mindede også om den danske derved, at den fortrinsvis begunstigede de grupper, der i forvejen var godt stillet. Den storstilede realbyrdeaflosning fra 1873 forandrede således arvefæestet til selveje. Statens og de private godsejeres overejendomsret og hjemfaldsret faldt bort uden erstatning. Alle årlige afgifter, hvad enten de bestod i naturalier, hoveri eller penge, blev regnet sammen til en pengesum. Bønderne kunne derpå vælge mellem en gang for alle at betale 18 gange denne årlige sum (for kanon 20 gange) eller forrente summen $i$ et længere åremål efter nærmere fastsatte regler. Realbyrdeafløsningen omfattede såvel de private godser som det statslige domænegods ${ }^{64}$. Gennem processer og politisk arbejde i den preussiske landdag lykkedes det imidlertid fæstebønderne $i$ amterne at slippe for at betale eller forrente afløsningssummen. De kom således gratis til selvejet ${ }^{65}$. 
Det tidsbegrænsede fæste blev der derimod stadig ikke rørt ved. I Svans var således endnu i $191136 \%$ af bønderne fæstere på åremål (1844: $41 \%$ af samtlige ejendomme) ${ }^{66}$. I Dänischwohld var der heller næppe sket de store ændringer. Da arbejdskraften på grund af udvandring og flytning til byerne blev knap, var godsejerne uvillige til at afløse det tilbageblevne hoveri, som altovervejende hvilede på husmændene. I de landsbyer, hvor fæsterne sad på åremålskontrakter, stod tiden stille op gennem 1800-tallet og begyndelsen af 1900-tallet. Først da de politiske magtforhold ændredes efter 1918, fandt problemet endelig sin løsning.

\section{NOTER OG HENVISNINGER}

1. Carsten Porskrog Rasmussen m.fl.: Det danske godssystem - udvikling og afvikling 1500-1919. Århus 1987 , især s. 8-10.

2. Bjørn Poulsen: Land - by - marked. Flensborg 1988. Jens Jessen: Die Entstehung und Entwicklung der Gutswirtschaft in Schleswig Holstein bis zum Beginn der Agrarreformen. Zeitschrift der Gesellschaft für Schleswig-Holsteinische Geschichte, Bd. 51, 1922, s. 1-206. J. Hvidtfeldt: Kampen om ophævelsen af livegenskabet i Slesvig og Holsten 1795-1805. Aabenraa 1963. Georg Rawitscher: Erb- und Zeitpächter auf den adligen Gütern der Ostküste Schleswig-Holsteins mit besonderer Berücksichtigung der Landschaften Angeln und Schwansen. Zeitschrift der Gesellschaft für Schleswig Holsteinische Geschichte, Bd. 41, 1911, s. 1-36. P. Kr. Iversen: Hoveri, stavnsbånd og livegenskab i Sønderjylland. Sønderjysk Månedsskrift 1988, s. 164-174. C. E. Andersen: Grams historie. Kbh. 1926, s. 1-223. Hans Schultz Hansen: Hovedgårdsdrift eller jordrente? System og økonomi på Trøjborg gods 1579-ca. 1660. Bol og By 1986: 1, s. 7-43.

3. W. Prange: Die Anfänge der grossen Agrarreformen in Schleswig-Holstein bis um 1771. Neumünster 1971, s. 249-265, 370-662. Hvidtfeldt anf. værk. Rawitscher s. 37-72. C. E. Andersen: 224313.

4. J. N. Schmidt: Slesvigs Land og Folk. Kbh. 1861, s. 124-140.

5. RA, Rentekammerets arkiv 352.4-6. Efterretninger om matrikelforholdene $i$ hertugdømmerne 1844. Tønder amts geestherreder: Sst. 352.2. Tabeller over bygninger i de slesvigske amter 1842.

6. Chronologische Sammlung der ... Verordnungen und Verfügungen für die Herzogthümer Schleswig und Holstein, 14.4.1766.

7. Sst. 14.4.1827 (kancelliskrivelse). N. Falck: Handbuch des Schleswig-Holsteinischen Privatrechts, V.1. Altona 1848, s. 220f. A. F. Bergsøe: Den danske Stats Statistik, II. Kbh. 1847, s. $118 f$.

8. RA, Rtk. 352.4-6.

9. Rtk. 352.4, redegørelse fra Tønder amtsstue for den manglende indsendelse af skema. Heraf fremgår, at der var over 1660 fæstesteder i geestherrederne, svarende til minimum $47 \%$ af det samlede antal ejendomme på 3556.

10. Falck s. 240-43. Bergsøe s. $119 \mathrm{f}$.

11. J. P. Trap: Statistisk-topographisk Beskrivelse af Hertugdømmet Slesvig, I-II. Kbh. 1864, passim.

12. M. Sering: Erbrecht und Agrarverfassung in Schleswig-Holstein. Berlin 1908, s. 334.

13. Chronologisk Samling af ... Love og Bekjendtgørelser for Hertugdømmet Slesvig, 16.4.1862.

14. Sst. 27.11.1863.

15. Sering anf. sted. Rawitscher s. 113 , note 1.

16. Som note 8 .

17. Provinzialhandbuch für Schleswig-Holstein und das Herzogthum Lauenburg. Zweiter Jahrgang. Kiel 1871. På grund af den ofte usikre angivelse af arealenhederne kan hovedgårdenes andel ikke udtrykkes i præcise procentsatser. 
18. Wilh. Hirschfeld: Wegweiser durch die Herzogthümer Schleswig und Holstein. Kiel 1847, s. 280282.

19. Som note 8 .

20. Rawitscher s. 109. Bergsøe s. 120.

21. Provinzialhandbuch, s. 56 .

22. Bemarkning i tabellen fra 1844, jfr. note 8. Trap, II. s. 327.

23. Tidende for Forhandlingerne ved Provindsialstænderne for Hertugdømmet Slesvig, 1836, s. 533.

24. Chronologisk Samling, 8.4.1856.

25. Bergsee s. 121.

26. Statistisk Tabelværk II:6. Kbh. 1852, s. 152f. Statistiske Meddelelser 3. Kbh. 1864-65, s. 63. Danske Slotte og Herregårde, 16. Kbh. 1967, s. 57, 84.

27. Provinzialhandbuch. En lidt usikker opgørelse giver, at $46 \%$ af bondejorden i Dänischwohld godsdistrikt i 1871 var bortfestet på åremål, $36 \%$ i Svans og $0 \%$ i L og 2 . angelske distrikt.

28. Som note 8.

29. Jens Christensen: Landbostatistik. Kbh. 1985, s. 44.

30. Chronologische Sammlung, 19.7.1805.

31. Sst. 19.9.1837.

32. Zeitung für die Verhandlungen der Provinzialstände des Herzogthums Schleswig 1838, s. 306315.

33. Hirschfeld s. 112.

34. Chronologisk Samling, 29.7.1850, paragraf 2.

35. Sst. 27.10.1852. Trap, II, s. 629 f.

36. Chronologisk Samling, 3.6.1853. Stændertidende 1853-54. Tillag II, sp. 72-79.

37. Chronologisk Samling, 3.8.1853.

38. Tidende for Forhandlingerne 1853-54. Tillæg II, sp. 115-124, 377-382.

39. J. Plesner: Partidannelsen i de slesvigske Provinsialstænder i Tiden mellem de to dansk-tyske krige. Sønderjyske Årbøger 1925, s. 225-281.

40. Chronologisk Samling, 6.2.1854.

41. Tidende for Forhandlingerne 1855. Tillag I, s. 22.

42. Hvidtfeldt s. 373-375, 396-399. Chronologische Sammlung, 19.12.1804 og 17.7.1805.

43. LA, Gråsten godsarkiv nr. 186-191. Sager vedr, tjenesteydelser m.m.

44. Zeitung für die Verhandlungen 1840 , sp. 378-380.

45. Tidende for Forhandlingerne 1836, s. 532-539.

46. Hirschfeld s. $278 f$.

47. Hans Schultz Hansen: Den danske bevægelse i Senderjylland ca. 1838-1850. Historie, ny række $18.3,1990$, s. $380-388$.

48. Hansen, Jørgen: Biskop Jørgen Hansens efterladte optegnelser om sit levnet og sit forhold til tidens begivenheder. 1904, 1-215, især s. 97.

49. Om folkerådet: Ernst Christensen: Landvæbningen på Als under Treårskrigen. Sønderjyske Årbøger 1962, s. 26f, 33ff.

50. LA, Augustenborg godsarkiv nr. 31. Fæstebøndernes ydelser 1726-1856.

51. LA, Gram og Nybal godsers arkiv nr. 141. Sager vedr. hoveri, agter og gangdage 1664-1881. Om Gram i perioden endv. C. E. Andersen, anf. vark, s. 314-402.

52. Søgård og Årtoft godsarkiv nr. 36. Sager vedr. hoveri og livegenskab samt afløsningen heraf 1694-1863.

53. Tidende for Forhandlingerne 1860 , s. 924.

54. Zeitung für die Verhandlungen 1840 , sp. 428. Rawitscher s. 97, 119, 154.

55. Tidende for Forhandlingerne 1856-57, s. 463-474.

56. Sst. 1860, s. $275-277,910-925$.

57. Plesner s. $260,272 \mathrm{ff}$.

58. Skema fra Søgård-Årtoft gods i godsarkivet, jfr. note 52. At skemaerne indkom, fremgår af RA, Ministeriet for Hertugdemmet Slesvigs arkiv, journal for 2. Dept. B 1862. Herfra henvises til "Stændersager", hvor de imidlertid ikke findes. Heller ikke Rawitscher kunne finde dem. Formentlig er de gået tabt. 
59. Tidende for Forhandlingerne 1863, s. 4. Plesner s. $276 \mathrm{ff}$.

60. RA, Min. f. Slesvig, forestillingsprotokol 1863, nr. 255 med trykt motivering. Chron. Saml. 6.9.1863.

61. Rawitscher s. 114f.

62. Carsten Porskrog Rasmussen m.fl. s. 35.

63. O. Hauser: Staatliche Einheit und regionale Vielfalt in Preussen. Neumünster 1967, passim. G. Japsen: Amtsforstanderinstitutionen i Nordslesvig. Festskrift til Johan Hvidtfeldt. Kbh. 1978, s. 189-207.

64. Rawitscher s. 116-119. Han hævder, at den preussiske lov modsat den slesvigske hoveriforordning af 1863 udmerkede sig ved ogsa at omfatte indforelse af selveje. Det er rigtigt, men omvendt gjaldt forordningen af 1863 også for bønder med tidsbegrænset faste.

65. H. Hejselbjerg Paulsen: To nordslesvigske politikere i ny belysning. Sønderjysk Månedsskrift 1977, s. 193-207.

66. Rawitscher s. 131. 